\title{
TINGKAT KEPATUHAN MINUM OBAT PASIEN HIPERTENSI JKN DI POLI PENYAKIT DALAM RSUD dr. DORIS SYLVANUS PALANGKA RAYA
}

\author{
Syahrida Dian Ardhany \\ Dosen Pengajar Program Studi DIII Farmasi, \\ Fakultas IImu Kesehatan, Universitas Muhammadiyah Palangkaraya \\ E-Mail: Chass501@gmail.com_
}

\begin{abstract}
ABSTRAK
Menurut WHO dan The International Society of Hypertension (ISH), terdapat 600 juta penderita hipertensi di seluruh dunia dan 3 juta diantaranya meninggal setiap tahunnya. WHO juga memperkirakan 1,56 miliar usia dewasa akan menderita hipertensi pada tahun 2025 (WHO-ISH Hypertension Guidline Committee, 2003). Ketidakpatuhan pada pasien hipertensi secara potensial dapat meningkatkan morbiditas, mortalitas dan biaya perawatan (Ogedegbe et al, 2009; Fung et al, 2007). Kepatuhan menjadi hal yang sangat penting bagi pasien hipertensi dalam mengontrol tekanan darah. Resiko terjadinya komplikasi kardiovaskuler dan kematian meningkat pada pasien yang tidak patuh terhadap rejimen terapinya (Nelson et al, 2010).

Penelitian ini merupakan cross sectional study data diambil selama 1 bulan (November 2015) di poli Penyakit Dalam RSUD dr. Doris Sylvanus Palangka Raya. Pasien hipertensi yang dapat berpartisipasi adalah pasien dengan usia $\geq 18$ tahun -65 tahun. Data diperoleh dengan cara melakukan wawancara menggunakan instrument kuisioner MMAS (Morisky Medication Adherence Scale).

Pada penelitian ini subyek yang memenuhi kriteria inklusi sejumlah 86 pasien. Hasil penelitian menunjukkan tingkat kepatuhan minum obat pasien hipertensi di Poli Penyakit Dalam RSUD dr. Doris Sylvanus Palangka Raya adalah tingkat kepatuhan sedang dengan score MMAS $=6,05 \pm 1,94$, selain itu baik usia maupun tingkat pendidikan tidak mempunyai pengaruh terhadap tingkat kepatuhan minum obat, yang dibuktikan dengan hasil uji SPSS menggunakan Kruskal Wallis Test $\mathrm{P}=0,806$ untuk usia dan $\mathrm{P}=0,178$ untuk tingkat pendidikan $(P<0,05)$. Pada penelitian ini dapat disimpulkan bahwa tingkat kepatuhan minum obat pasien hipertensi di poli penyakit dalam RSUD dr. Doris Sylvanus Palangka Raya periode November 2015 adalah tingkat kepatuhan sedang.
\end{abstract}

Kata kunci : Hipertensi, MMAS, Palangka Raya

\section{PENDAHULUAN}

Hipertensi merupakan salah satu penyebab kematian. Komplikasi pembuluh darah yang disebabkan hipertensi dapat menyebabkan penyakit jantung koroner, infark jantung, stroke, dan gagal ginjal. (Alhalaiqa et.al, 2012). Menurut WHO dan The International Society of Hypertension (ISH), terdapat 600 juta penderita hipertensi di seluruh dunia dan 3 juta diantaranya meninggal setiap tahunnya. WHO juga memperkirakan 1,56 miliar usia dewasa akan menderita hipertensi pada tahun 2025 (WHO-ISH Hypertension Guidline Committee, 2003). Di Asia Tenggara, sekitar sepertiga dari seluruh jumlah penduduk usia dewasa menderita hipertensi (World Health Organization, 2011). Prevalensi hipertensi di Indonesia terus meningkat dari 8,3\% (SKRT 
1995) menjadi 14\% (SKRT 2004) dan berdasarkan hasil riset kesehatan dasar (Riskesdas) 2007, prevalensi hipertensi di Indonesia mencapai $31,7 \%$ dari total penduduk dewasa (Rahajeng \& Tuminah, 2009).

Kepatuhan biasanya menjadi masalah pada pasien-pasien penyakit kronik yang membutuhkan modifikasi gaya hidup dan terapi jangka panjang. Ketidakpatuhan pada pasien hipertensi secara potensial dapat meningkatkan morbiditas, mortalitas dan biaya perawatan (Ogedegbe et al, 2009; Fung et al, 2007). Beberapa alasan pasien tidak menggunakan obat antihipertensi adalah dikarenakan sifat penyakit yang secara alami tidak menimbulkan gejala, terapi jangka panjang, efek samping obat, regimen terapi kompleks, pemahaman yang kurang tentang pengelolaan dan resiko hipertensi serta biaya pengobatan yang relatif tinggi (Morgado et al, 2011; Lin et al, 2007).

Kepatuhan menjadi hal yang sangat penting bagi pasien hipertensi dalam mengontrol tekanan darah. Menurut Nelson et al (2010) Resiko terjadinya komplikasi kardiovaskuler dan kematian meningkat pada pasien yang tidak patuh terhadap rejimen terapinya.

Skala self-report untuk menilai kepatuhan penggunaan obat antihipertensi telah dikembangkan oleh Morisky et al., (2008). Penelitian untuk menguji psikometri dan prediksi validitas dari struktur self report medication adherence diujikan pada 1367 pasien hipertensi. Self report kepatuhan penggunaan obat diukur dengan new 8 item self report Morisky Medication Adherence Scale (MMAS).

Berdasarkan hal tersebut di atas, maka perlu dilakukan penelitian untuk mengetahui tingkat kepatuhan minum obat pasien hipertensi rawat jalan di Poliklinik Penyakit Dalam RSUD dr. Doris Sylvanus Palangka Raya menggunakan kuisoner MMAS.

\section{METODE}

Penelitian ini merupakan cross sectional study. Pada penelitian ini pasien yang direkrut adalah pasien hipertensi dengan usia 18-65 tahun yang menjalani rawat jalan di Poli Penyakit Dalam RSUD dr. Doris Sylvanus Palangka Raya.

Data diambil selama 1 bulan (November 2015). Pengambilan data dilakukan dengan wawancara menggunakan kuisioner MMAS (Morisky Medication Adherence Scale) dimana terdiri dari 8 pertanyaan.

Tingkat kepatuhan terapi dikategorikan menjadi 3 tingkatan yaitu kepatuhan tinggi (nilai MMAS sama dengan 8), kepatuhan sedang (nilai MMAS 6 sampai kurang dari 8) dan kepatuhan rendah (nilai MMAS kurang dari 6).

Uji validitas dan reabilitas kuisioner telah dilakukan oleh Alfian (2013) pada 30 pasien. Uji validitas menunjukkan bahwa kuisoner valid dan hasil analisis realibilitas menggunakan uji statistik Cronbach's alpha adalah 0,641 yang mengindikasikan bahwa kuisioner realibel untuk digunakan pada 
penelitian ini. Banyaknya sampel penelitian adalah semua populasi terjangkau yang memenuhi kriteria inklusi. Perhitungan besar sampel pada penelitian ini berdasarkan populasi pasien hipertensi pada bulan sebelumnya (Oktober 2015) yaitu 108 orang kemudian sampel ditentukan berdasarkan tabel Krejcie Morgan, yaitu sebanyak 86 pasien hipertensi.

Kriteria inklusi :

1. Pasien dewasa laki-laki dan perempuan berusia antara 18-65 tahun.

2. Pasien hipertensi yang melakukan kontrol di poliklinik penyakit dalam RSUD dr. Doris Sylvanus Palangka Raya.

3. Menerima minimal 1 obat hipertensi.

4. Tidak buta huruf.

5. Bersedia mengikuti penelitian.

Kriteria Eksklusi:

1. Buta huruf

2. Hamil

3. Tuli

Pada penelitian ini dilakukan wawancara kepada pasien untuk konfirmasi data yang tertulis dalam kuisioner. Pasien diminta melengkapi lembar kuisioner kepatuhan minum obat mengggunakan kuisioner MMAS. Hasil skoring MMAS akan diuji menggunakan SPSS versi 16.0

\section{HASIL DAN PEMBAHASAN}

Sebanyak 86 pasien hipertensi yang memenuhi kriteria inklusi yang dimasukkan pada penelitian ini yang menjalani rawat jalan di poliklinik penyakit dalam RSUD dr. Doris Sylvanus Palangka Raya periode November 2015. Pengambilan subjek penelitian dilakukan dengan metode consecutive sampling yaitu semua objek yang memenuhi kriteria inklusi dimasukkan sebagai subjek dalam penelitian. Karakterisitik sosio-demografi pasien disajikan pada Tabel I.

Pada penelitian ini, berdasarkan data karakterisitik pasien dapat dilihat bahwa mayoritas subjek penelitian adalah perempuan, usia mayoritas pasien rentang 45 sampai dengan 60 tahun, sedangkan tingkat pendidikan didominasi dengan pendidikan SLTA (sekolah lanjutan tingkat atas).

Kepatuhan biasanya menjadi masalah pada pasien-pasien penyakit kronik yang membutuhkan modifikasi gaya hidup dan terapi jangka panjang. Ketidakpatuhan pada pasien hipertensi secara potensial dapat meningkatkan morbiditas, mortalitas dan biaya perawatan (Ogedebge et al, 2009; Fung et al , 2007).

Beberapa alasan pasien tidak menggunakan obat antihipertensi adalah dikarenakan sifat penyakit yang secara alami tidak menimbulkan gejala, terapi jangka panjang, efek samping obat, regimen terapi yang kompleks, pemahaman yang kurang tentang pengelolaan dan resiko hipertensi serta biaya pengobatan yang relatif tinggi (Morgado et al, 2011; Lin, Huang, Yang, Wu, Chang \& Lu, 2007). 
Tabel I. Karakteristik pasien hipertensi di RSUD dr. Doris Sylvanus Palangka Raya.

\begin{tabular}{lll}
\hline & $\mathbf{n = 8 6}$ & $\mathbf{\%}$ \\
\hline Jenis Kelamin & & \\
Laki-laki & 28 & 32,6 \\
Perempuan & 58 & 67,4 \\
Usia & 16 & 18,6 \\
$<45$ tahun & 56 & 65,1 \\
$45-60$ tahun & 14 & 16,3 \\
$>60$ tahun & & \\
Pendidikan & 20 & 23,3 \\
0-9 tahun atau < SLTA & 44 & 51,2 \\
10-12 tahun atau = SLTA & 22 & 25,6 \\
$>12$ tahun atau > SLTA & &
\end{tabular}

Tabel II. Rata-rata score MMAS Pasien hipertensi di poli penyakit dalam RSUD dr. Doris Sylvanus Palangka Raya

\begin{tabular}{cclll}
\hline $\mathbf{N}$ & $\begin{array}{c}\text { Score } \\
\text { MMAS }\end{array}$ & Tingkat kepatuhan & & \\
\hline 86 & $6,05 \pm 1,94$ & Sedang & & \\
\hline
\end{tabular}

Kepatuhan menjadi hal yang sangat kardiovaskuler dan kematian meningkat penting bagi pasien hipertensi dalam mengontrol tekanan darah. Menurut National pada pasien yang tidak patuh terhadap Health And Nutrition Examination Survey rejimen terapinya (Nelson et al , 2006). Di (NHES III), paling sedikit $30 \%$ pasien Indonesia, dengan tingkat kesadaran yang hipertensi di Amerika tidak menyadari lebih rendah, jumlah pasien yang tidak kondisi mereka dan hanya $31 \%$ pasien yang menyadari bahwa dirinya menderita diobati mencapai target tekanan darah yang hipertensi dan tidak mematuhi minum obat diinginkan dibawah 140/90mmHg (Hajjar \& lebih besar (Depkes, 2006). Kotchen, 2003). 
Tabel III. Rata-rata score MMAS berdasarkan karakteristik pasien hipertensi di poli penyakit dalam RSUD dr. Doris Sylvanus Palangka Raya

\begin{tabular}{|c|c|c|c|c|}
\hline & $\mathbf{n}$ & $\begin{array}{r}\text { Rata-rata } \\
\text { MMAS }\end{array}$ & Score & $P$ \\
\hline Jenis kelamin & & & & \multirow[b]{2}{*}{0,024} \\
\hline $\begin{array}{l}\text { Laki-laki } \\
\text { Perempuan }\end{array}$ & $\begin{array}{l}28 \\
58\end{array}$ & $\begin{array}{l}6,55 \pm 2,00 \\
5,80 \pm 1,87\end{array}$ & & \\
\hline Usia & & & & \multirow{5}{*}{0,806} \\
\hline$<45$ tahun & 16 & $6,06 \pm 1,65$ & & \\
\hline $45-60$ tahun & 56 & $5,98 \pm 2,04$ & & \\
\hline $\begin{array}{l}>60 \text { tahun } \\
\text { Pendidikan }\end{array}$ & 14 & $6,29 \pm 1,90$ & & \\
\hline $0-9$ tahun atau $<$ & 20 & $5,74 \pm 2,19$ & & \\
\hline $\begin{array}{l}\text { SLTA } \\
\text { 10-12 tahun atau = } \\
\text { SLTA }\end{array}$ & 44 & $6,47 \pm 1,58$ & & \multirow[t]{2}{*}{0,178} \\
\hline $\begin{array}{l}>12 \text { tahun atau > } \\
\text { SLTA }\end{array}$ & 22 & $5,48 \pm 2,22$ & & \\
\hline
\end{tabular}

Salah satu cara untuk menilai Pada penelitian ini dari delapan puluh kepatuhan minum obat pasien hipertensi enam subjek didapatkan rata-rata kepatuhan adalah dengan menggunakan kuisioner minum obat $6,05 \pm 1,94$ atau dapat MMAS (Morisky Medication Adherence dikatakan bahwa tingkat kepatuhan minum Scale). Saat ini telah dikembangkan cara pengukuran yang lebih objektif untuk mengevaluasi kepatuhan pasien dalam pengobatan yakni the new 8-item selfreport Morisky Medication Adherence Scale (MMAS) (Morisky et al, 2008). MMAS merupakan pendekatan yang lebih praktis dan valid untuk mengidentifikasikan low adherence dalam regimen pengobatan kronis pada pasien rawat jalan. Tingkat kepatuhan terapi dikategorikan menjadi 3 tingkatan yaitu kepatuhan tinggi (nilai MMAS sama dengan 8), kepatuhan sedang (nilai MMAS 6 sampai kurang dari 8) dan kepatuhan rendah (nilai MMAS kurang dari $6)$. obat pasien hipertensi di poli penyakit dalam RSUD dr. Doris Sylvanus Palangka Raya adalah tingkat kepatuhan sedang. Hal ini mungkin disebabkan karena ketidaksengajaan (contohnya kelalaian atau terlupa minum obat), sengaja tidak minum obat saat merasa penyakitnya bertambah parah atau membaik serta kurangnya pengetahuan tentang hipertensi dan tujuan pengobatannya. Pada penelitian ini terdapat perbedaan bermakna score MMAS atau kepatuhan minum obat antara laki-laki dan perempuan $(P=0,024)$. Hasil rata-rata score MMAS dapat dilihat pada Tabel II. Usia dan pendidikan pada penelitian tidak terdapat perbedaan bermakna yang berarti bahwa dari segi usia (18-65 tahun) maupun 
pendidikan tidak berpengaruh terhadap kepatuhan minum obat pasien hipertensi di poli penyakit dalam RSUD dr. Doris Sylvanus Palangka Raya (Tabel III).

\section{KESIMPULAN}

Kesimpulan yang dihasilkan dari penelitian ini adalah sebagai berikut:

1. Tingkat kepatuhan minum obat pasien hipertensi di poli penyakit dalam RSUD dr. Doris Sylvanus Palangka Raya adalah tingkat kepatuhan sedang $(6,05 \pm 1,94)$.

2. Tidak terdapat perbedaan bermakna baik usia $(P=0,806)$ maupun tingkat pendidikan $(P=0,178)$ terhadap kepatuhan minum obat pasien hipertensi di poli penyakit dalam RSUD dr. Doris Sylvanus Palangka Raya.

3. Terdapat perbedaan bermakna antara laki-laki dan perempuan terhadap tingkat kepatuhan minum obat pasien hipertensi di poli penyakit dalam RSUD dr. Doris Sylvanus Palangka Raya $(P=0,024)$.

\section{DAFTAR PUSTAKA}

1. Alhaiqa, F., Deane, K.H.O., Nawafleh, A.H., Clark, A., Gray, R., 2012, Adherence therapy for

7. Morisky, D.E., Ang, A., Krouselwood, M., \& Ward, H. J, 2008, Predictive validity of a medication adherence measure in an outpatient setting. Journal of Clinical Hypertension, 10 (5), 348-354. medication non compliant patients with hypertension:a randomised controlled trial, Journal of Human Hypertension 26, 117-126.

2. Depkes, 2006, Pharmaceutical Care Untuk Penyakit Hipertensi, Direktorat Bina Farmasi Komunitas dan Klinik, Depkes RI, Jakarta.

3. Fung, V., Huang, J., Brand, R., Newhouse, J.P., \& Hsu, J, 2007, Hypertension treatment in a medicare population: Adherence and systolic blood pressure control. Clinical Therapeutics, 29 (5), 972984.

4. Hajjar, L., \& Kotchen, T.A, 2003, Trends in prevalence, awareness, treatment, and control of hypertension in the United States, 1998-2000. JAMA, 290, 199-206.

5. Lin, Y., Huang, Y., Yang, Y., Wu, J., Chang, C., \& Lu, F, 2007, Adherence to Antihypertensive medications among the elderly: a Communitybased survey in Tainan city, Southern Taiwan. Taiwan Geriatr Gerontrol, 2 (3), 176-189.

6. Morgado, M., Rolo, S., \& Branco, M.C, 2011, Pharmacist intervention program to enhance hypertension control: a Randomised controlled trial. Int J Clin Pharm, 33, 133-140.

8. Nelson, M.R., Reid, C.M., Ryan, P., Willson, K., \& Yelland, L, 2006, Selfreported adherence with medication and cardiovascular disease outcomes in the Second Australian National Blood Pressure Study 
(ANBP2. Medical Journal of Australia, 185 (9), 487-489.

9. Ogedegbe, G., Tobin, J.N., Fernandez, S., Gerin, W., Diazgloster, M., Cassells, A., Khalida, C., Pickering, T., Schoenthaler, A., \&

10. Ravanell, J, 2009, Counseling African Americans To Control Hypertension (CAATCH) trial: a Multi-level intervention to improve blood pressure control in hypertension blacks, Journal of The American Heart Association, 2, 249256.
11. Rahajeng, E., dan Tuminah, S., 2009. Prevalensi hipertensi dan determinannya di Indonesia. Majalah Kedokteran Indonesia, 59 (12).

12. WHO-ISH Hypertemsion Guidline Committee, 2003. Guidlines of the management of hypertension. Journal Hypertension, 21 (11), 19831992 
